\title{
Prevalence, impact, and management of depression and anxiety in patients with HIV: a review
}

\author{
This article was published in the following Dove Press journal: \\ Neurobehavioral HIV Medicine \\ 5 May 2016 \\ Number of times this article has been viewed
}

Suprakash Chaudhury'

Ajay Kumar Bakhla ${ }^{2}$

Rajiv Saini ${ }^{3}$

'Department of Psychiatry, Pravara Institute of Medical Sciences (Deemed University), Loni, Maharashtra, ${ }^{2}$ Department of Psychiatry, Rajendra Institute of Medical Sciences, Ranchi, Jharkhand, ${ }^{3}$ Department of Psychiatry, Armed Forces Medical College (AFMC), Pune, Maharashtra, India
Correspondence: Suprakash Chaudhury Department of Psychiatry, Pravara Institute of Medical Sciences (Deemed University), Rural Medical College, Loni, Ahmednagar, Maharashtra 4I3736, India Email suprakashch@gmail.com
Abstract: The prevalence of depression and anxiety in people living with HIV/AIDS (PLWHA) ranges from $7.2 \%$ to $71.9 \%$ and $4.5 \%$ to $82.3 \%$, respectively. This wide variation is attributed to differences in sample size and characteristics, and methodology for assessment of anxiety and depression. Moreover, anxiety and depression increase the morbidity of HIV by poor adherence to treatment and various other significant mechanisms. Early identification and effective management of these disorders is associated with improved antiretroviral adherence and improved quality of life in PLWHA. Different treatment modalities, including pharmacological and nonpharmacological therapies, are used for the management of anxiety and depression in PLWHA. Benzodiazepines are indicated for short periods of time. Clonazepam and lorazepam are safe in terms of drug-drug interactions and may be preferred. Selective serotonin reuptake inhibitors are safer than tricyclic antidepressants. Though the different selective serotonin reuptake inhibitors are supposed to be equally effective, to avoid interactions with antiretrovirals, the better options are sertraline, citalopram, and escitalopram. Various nonpharmacological therapies, including cognitive behavior therapy, interpersonal therapy, supportive psychotherapy, cognitive-behavioral-oriented group psychotherapy, experiential group psychotherapy, cognitive-behavioral stress management, stress management interventions, cognitive remediation therapy, mindfulness-based therapy, and aerobic and resistance exercise have been reported to be useful in treating depression among PLWHA. However, definitive evidence to decide which nonpharmacological intervention is most beneficial for the management of anxiety and depression in PLWHA is still required.

Keywords: tricyclic antidepressants, benzodiazepines, SSRI, CBT, interpersonal therapy, mindfulness based therapy

\section{Introduction}

The human immunodeficiency virus (HIV) is transmitted through sexual intercourse (unprotected anal or vaginal) and blood contamination, as well as during pregnancy, childbirth, and breastfeeding from the mother. The virus infects cells of the immune system, thereby weakening it, as a result of which the individual becomes more susceptible to various infections. The World Health Organization (WHO) states that the infection can advance to a final stage in 10-15 years (antiretroviral drugs can slow down the process even further), known as the acquired immunodeficiency syndrome (AIDS). The diagnosis of HIV infection in people $\geq 18$ months is defined by WHO as:

positive HIV antibody testing, which is confirmed by a second HIV antibody test relying on different antigens or of different operating characteristics; and/or positive virological 
test for HIV or its components confirmed by a second virological test obtained from a separate determination. ${ }^{1,2}$

Once a person's HIV-positive status is confirmed, he or she has to make some life-changing decisions. First, they have to make the important decision about whether to inform their significant other of their HIV-positive status. Second, they have to decide about undergoing treatment and continuing it regularly. Finally, they have to decide about future sexual relations and whether they should have children. As a result of their decision, they may become isolated with reduced social support, may refuse treatment, or even develop psychiatric illnesses such as anxiety and depression. ${ }^{3}$

The most common neuropsychiatric disorder in people living with HIV/AIDS (PLWHA) is depression. ${ }^{4}$ Similarly, the prevalence of an anxiety disorder in PLWHA is more common than in the general population. ${ }^{5}$ Depression and anxiety are associated with an increase in morbidity and mortality in PLWHA and adversely affect the adherence to antiretroviral therapy (ART), quality of life (QoL), and health-related QoL. ${ }^{6-8}$ Improvement in overall functioning of PLWHA and adherence to ART may follow effective treatment of depression and anxiety. ${ }^{9,10}$

A complex relationship exists between depression and HIV infection. Depression is both a risk factor and a consequence of HIV infection. ${ }^{11,12}$ In PLWHA, contributory factors for depression include comorbidities, coping with the prospects of illness and death, neurobiological changes related to persistent central nervous system (CNS) infections due to HIV, social stigma, sexual dysfunction, and side effects of ART. ${ }^{13,14}$ Depression can easily remain unrecognized and untreated in PLWHA. ${ }^{15}$ A meta-analytic study concluded that the development of depression in PLWHA was not associated with the sexual orientation of patients or the disease stage of the HIV infection. ${ }^{16}$ However, despite a large number of studies, clear answers are lacking in many areas relating to anxiety and depression in PLWHA. This review aims to summarize the recent literature and research related to the prevalence, impact, and management of comorbid depression and anxiety in PLWHA. Since there is more literature on depression in PLWHA, this review reflects that bias.

\section{Methodology}

Literature was searched for any articles that related to HIV, depression, anxiety prevalence, impact and treatment during February and May 2015. A PubMed search strategy was used with the following paired phrases: "HIV Depression Anxiety", "HIV Depression Anxiety Prevalence", "HIV
Depression Anxiety Impact", and "HIV Depression Anxiety Treatment". A Google search was done with the search term "HIV Depression Anxiety, Prevalence, Impact and Treatment". Only full articles were downloaded and included for this review. During the PubMed search, using the term "HIV Depression Anxiety prevalence" returned 336 articles; similarly, "HIV Depression Anxiety impact" returned 140 articles and "HIV Depression Anxiety treatment" returned 482 articles. This initial search was done without any restrictions on the year of publication or the type of article. All publications containing information on any of the following endpoints in relation to HIV patients were shortlisted: depression, anxiety, prevalence, impact, and management (treatment), and abstracts of the articles were read to screen them. Thereafter, the full text of the selected articles were reviewed; recently published articles were preferred over older ones, and many cross-references were also checked and the articles found. Articles were excluded if they were not written in English, were related to child and adolescent population, or were of unrelated findings. Official documents from the WHO were also screened; in addition, some other articles were identified through Google and from the personal knowledge of the authors. In total, the findings of $\sim 150$ articles were reviewed.

\section{Results Incidence}

There were very few results relating to studies estimating the incidence of depression or anxiety. A study that analyzed a sample of 2,737 PLWHA reported that the incidence of depression was 2.2 per 100 person years. ${ }^{17}$ Another study reported an incidence of 1.89 per 100 person years for depression and 1.27 per 100 person years for generalized anxiety. ${ }^{18}$

\section{Prevalence}

In contrast to the few studies estimating the incidence, there were abundant studies estimating the prevalence of depression and anxiety. We scrutinized $\sim 40$ and 30 studies, respectively, for depression and anxiety prevalence. There was a wide range of differences on the prevalence across these studies, as summarized in Tables 1 and 2 for depression and anxiety, respectively. There was a problem regarding the use of different methodologies and different definitions. In a recent Nigerian study, depressive symptoms were present in at least $49 \%$ of PLWHA. ${ }^{19}$ A psychiatric disorder was present in almost half of the 2,864 PLWHA, including $36 \%$ 
Table I Prevalence rate of depression in patients with HIV

\begin{tabular}{|c|c|c|c|c|}
\hline Location, reference & Scale used & $\begin{array}{l}\text { Sample } \\
\text { size }\end{array}$ & $\begin{array}{l}\text { Depression } \\
\text { prevalence, \% }\end{array}$ & Associated findings \\
\hline $\begin{array}{l}\text { Nigeria, Sale and } \\
\text { Gadanya }^{25}\end{array}$ & HADS, ICD 10 & 162 & 39.9 & $\begin{array}{l}\text { Depression was associated with the stage of HIV illness, } \\
\text { CD4 } 4^{+} \text {count level, poverty, low social support, and } \\
\text { inability to tolerate ART }\end{array}$ \\
\hline $\begin{array}{l}\text { People's Republic of } \\
\text { China, Lu et al }{ }^{26}\end{array}$ & SRDS & 102 & 67.65 & $\begin{array}{l}\text { Depression and anxiety were associated with low } \mathrm{CD}^{+} \\
\text {T-lymphocyte counts }\end{array}$ \\
\hline $\begin{array}{l}\text { Kenya, Musisi and } \\
\text { Kinyanda }^{27}\end{array}$ & ICD 10 & 82 & 40.8 & $\begin{array}{l}\text { Other comorbid disorders included anxiety, } \\
\text { somatization, seizures, mania, and HIV-associated } \\
\text { progressive encephalopathy }\end{array}$ \\
\hline $\begin{array}{l}\text { Thailand, Nüesch } \\
\text { et } \mathrm{al}^{28}\end{array}$ & HADS & 251 & 7.2 & ART improved mental health and QoL \\
\hline $\begin{array}{l}\text { Tanzania, Marwick } \\
\text { and Kaaya }{ }^{29}\end{array}$ & CIS-R & 220 & 15.5 & $\begin{array}{l}\text { During HIV care, co-morbid psychiatric disorders should } \\
\text { be identified and managed }\end{array}$ \\
\hline $\begin{array}{l}\text { Jamaica, Clarke et al, } \\
(2010)^{30}\end{array}$ & PHQ-9 & 63 & 43 & $\begin{array}{l}\text { Age, gender, marital status, major stress, living } \\
\text { conditions, ART, and CD4 } 4^{+} \text {count were not associated } \\
\text { with depression }\end{array}$ \\
\hline $\begin{array}{l}\text { India, Sivasubramanian } \\
\text { et } \mathrm{a}^{31}\end{array}$ & M.I.N.I.; DSM-IV & 150 & 29 & $\begin{array}{l}\text { Depression was associated with low self-esteem and low } \\
\text { levels of social support }\end{array}$ \\
\hline $\begin{array}{l}\text { Albania, Morrison } \\
\text { et a }\left.\right|^{32}\end{array}$ & $\begin{array}{l}\text { Semistructured } \\
\text { interview }\end{array}$ & 79 & 62.3 & $\begin{array}{l}\text { Depression was significantly associated with anxiety, } \\
\text { greater number of barriers to care, and greater medical } \\
\text { and social needs }\end{array}$ \\
\hline USA, Bhatia et al ${ }^{33}$ & CES-D & 180 & 67 & $\begin{array}{l}\text { Multivariate analysis revealed the association of } \\
\text { depression with female gender, low income, history of } \\
\text { psychoactive substance abuse, and low access to medical } \\
\text { care }\end{array}$ \\
\hline $\begin{array}{l}\text { Uganda, Kinyanda } \\
\text { et al }\left.\right|^{34}\end{array}$ & M.I.N.I. & 618 & 8.1 & $\begin{array}{l}\text { Depression was associated with psychosocial } \\
\text { impairment, adverse life events, PTSD, GAD, and past } \\
\text { history of deliberate self-harm }\end{array}$ \\
\hline India, Agarwal et a ${ }^{35}$ & HADS & 50 & 30 & $46 \%$ of PLWHA had low psychological well-being \\
\hline $\begin{array}{l}\text { South Africa, Pappin } \\
\text { et } \mathrm{al}^{36}\end{array}$ & HADS & 716 & 25.4 & Depression was associated with stigma \\
\hline $\begin{array}{l}\text { Cameroon, L'akoa } \\
\text { et } \mathrm{al}^{37}\end{array}$ & PHQ-9 & 100 & 63 & $\begin{array}{l}\text { Newly diagnosed HIV-infected patients had higher } \\
\text { prevalence of depression, severe immunosuppression, } \\
\text { and harmful use of alcohol associated with depression }\end{array}$ \\
\hline $\begin{array}{l}\text { People's Republic of } \\
\text { China, Su et al }{ }^{38}\end{array}$ & $\mathrm{BDI}$ & 258 & 71.9 & $\begin{array}{l}\text { Depression was associated with less income and high } \\
\text { perceived stress }\end{array}$ \\
\hline India, Talukdar et al ${ }^{39}$ & $\mathrm{BDI}$ & 175 & 56 & $\begin{array}{l}\text { Poor QoL was associated with depression and high } \\
\text { neuroticism score }\end{array}$ \\
\hline $\begin{array}{l}\text { Nigeria, } \\
\text { Olagunju et al }{ }^{40}\end{array}$ & SCID-NP & 295 & 14.9 & $\begin{array}{l}\text { Compared to the general population, PLWHA suffer } \\
\text { from more psychiatric disorders }\end{array}$ \\
\hline $\begin{array}{l}\text { South Korea, } \\
\text { Song et } \mathrm{al}^{41}\end{array}$ & $\mathrm{BDI}$ & 82 & 21 & $\begin{array}{l}\text { Depression was associated with poor adherence and } \\
\text { anxiety. Comorbidities and unemployment were risk } \\
\text { factors for depression. }\end{array}$ \\
\hline $\begin{array}{l}\text { People's Republic of } \\
\text { China, Liu et al }{ }^{42}\end{array}$ & CES-D & 320 & 66.3 & $\begin{array}{l}\text { Depression and anxiety in PLWHA could be reduced by } \\
\text { high social support }\end{array}$ \\
\hline India, Chauhan et al ${ }^{43}$ & HADS & 100 & 39 & $\begin{array}{l}\text { Asymptomatic PLWHA had significantly higher } \\
\text { prevalence of alcohol dependence, adjustment disorder, } \\
\text { and sexual dysfunction compared to control subjects }\end{array}$ \\
\hline Israel, Levy et al| ${ }^{44}$ & PHQ-9 & 57 & 24 & $\begin{array}{l}\text { Neurocognitive disturbances and psychiatric illnesses } \\
\text { were common in asymptomatic PLWHA, but were } \\
\text { independent of the time of being positive, immunological } \\
\text { status, viral load, or treatment received }\end{array}$ \\
\hline $\begin{array}{l}\text { South Africa, } \\
\text { Nel and Kagee }\end{array}$ & BDI II & 101 & 40.4 & $\begin{array}{l}\text { ART adherence was significantly related to depressive } \\
\text { symptoms on biserial correlations and logistic regression } \\
\text { analysis }\end{array}$ \\
\hline
\end{tabular}


Table I (Continued)

\begin{tabular}{|c|c|c|c|c|}
\hline Location, reference & Scale used & $\begin{array}{l}\text { Sample } \\
\text { size }\end{array}$ & $\begin{array}{l}\text { Depression } \\
\text { prevalence, \% }\end{array}$ & Associated findings \\
\hline Romania, Largu et al ${ }^{46}$ & BDI II & 146 & $\begin{array}{l}41 \text { (moderate } \\
\text { in } 14 \% \text {; mild in } \\
27 \%)\end{array}$ & $\begin{array}{l}\text { PLWHA were afraid (of death, complications, other } \\
\text { people's reaction to the diagnosis), confused (in terms } \\
\text { of diagnosis, the mode of infection, the future), angry } \\
\text { (against the source of infection, themselves, God), felt } \\
\text { guilty and blamed themselves }\end{array}$ \\
\hline Malawi, Kim et $\mathrm{al}^{47}$ & CDRS-R & 562 & 18.9 & 7.1\% of PLWHA had suicidal ideation \\
\hline $\begin{array}{l}\text { Germany, } \\
\text { Kittner et al }\end{array}$ & HADS & 80 & $\begin{array}{l}30 \text { (male) and } \\
47 \text { (female) }\end{array}$ & $\begin{array}{l}\text { Guilt for the HIV infection was present in } 36 \% \text { of } \\
\text { PLWHA }\end{array}$ \\
\hline $\begin{array}{l}\text { India, Bhatia and } \\
\text { Munjal }^{49}\end{array}$ & CES-D & 160 & 58.7 & $\begin{array}{l}\text { Depression was associated with low family income, } \\
\text { unemployment, low education, not married, migration, } \\
\text { poor relationship with spouse, poor social support, and } \\
\text { visiting commercial sex workers }\end{array}$ \\
\hline $\begin{array}{l}\text { People's Republic of } \\
\text { China, Sun et al }{ }^{50}\end{array}$ & CES-D & 772 & 73.1 & $\begin{array}{l}\text { Depression was associated with health status, perceived } \\
\text { social support, job, and gender }\end{array}$ \\
\hline $\begin{array}{l}\text { People's Republic of } \\
\text { China, Qiu et } \text { al }^{51}\end{array}$ & PHQ-9 & 370 & 40.3 & $\begin{array}{l}\text { Depression was associated with employment status, } \\
\text { sexual orientation, resident status, emergence of HIV- } \\
\text { related symptoms, stress, and social support }\end{array}$ \\
\hline $\begin{array}{l}\text { Haitian females in } \\
\text { USA, Glémaud et } \text { al }^{52}\end{array}$ & & 96 & 49 & $\begin{array}{l}\text { I } 2.5 \% \text { of subjects gave a history of abuse; } 34 \% \text { of } \\
\text { subjects had PTSD }\end{array}$ \\
\hline Lowther et $\mathrm{al}^{53}$ & $\begin{array}{l}\text { Systematic } \\
\text { review }\end{array}$ & $\begin{array}{l}66 \text { original } \\
\text { studies }\end{array}$ & 33.60 & $\begin{array}{l}\text { Low- and middle-income countries had a higher } \\
\text { prevalence of depression ( } 41.36 \%) \text { compared to high- } \\
\text { income countries }(25.81 \%)\end{array}$ \\
\hline $\begin{array}{l}\text { Western Europe and } \\
\text { Canada, Robertson } \\
\text { et } \mathrm{al}^{5}\end{array}$ & HADS & 2,863 & $\begin{array}{l}\text { I5.7 (I4.3\% of } \\
\text { male and } 17.9 \% \\
\text { of female) }\end{array}$ & $\begin{array}{l}\text { Depression occurred significantly more often in females } \\
\text { compared to males }\end{array}$ \\
\hline $\begin{array}{l}\text { South Korea, } \\
\text { Kee et } \mathrm{al}^{54}\end{array}$ & $\mathrm{BDI}$ & 840 & 36 & $\begin{array}{l}\text { Both anxiety and depression were associated with } \\
\text { persistent symptoms, alcohol and tobacco use, and } \\
\text { marital status }\end{array}$ \\
\hline Brazil, Nomoto et al ${ }^{55}$ & $\mathrm{BDI}$ & 59 & 61 & $\begin{array}{l}\text { Depression was significantly associated with low income, } \\
\text { low social class, and poor QoL }\end{array}$ \\
\hline Denmark, Slot et $\mathrm{al}^{56}$ & $\mathrm{BDI}$ & 212 & 35 & $\begin{array}{l}\text { Depression was associated with stress, poor health, } \\
\text { dissatisfaction with life situation, ART nonadherence, and } \\
\text { past history of alcohol abuse or psychiatric treatment }\end{array}$ \\
\hline
\end{tabular}

Abbreviations: AIDS, acquired immunodeficiency syndrome; ART, antiretroviral therapy; BDI, Beck Depression Inventory; CDRS-R, Children's Depression Rating ScaleRevised; CES-D, Center for Epidemiologic Studies Depression Scale; CIS-R, Clinical Interview Schedule-Revised; DSM, Diagnostic and Statistical Manual of Mental Disorders; GAD, generalized anxiety disorder; HADS, Hospital Anxiety and Depression Scale; HIV, human immunodeficiency virus; ICD, International Classification of Diseases; M.I.N.I., Mini International Neuropsychiatric Interview; PHQ-9, Patient Health Questionnaire; PLWHA, persons living with HIV/AIDS; PTSD, post-traumatic stress disorder; QoL, quality of life; SCID-NP, Structured Clinical Interview for DSM-IV non-patient; SRDS, Self-rating depression scale.

having depression and $16 \%$ with generalized anxiety disorder (GAD). Nearly $40 \%$ of subjects were using an illicit substance and $12 \%$ were drug dependent. ${ }^{4}$ Prevalence of depression is found to be very high among PLWHA, as compared general population. ${ }^{20,21}$ An early meta-analysis reported that the prevalence of depression in PLWHA was $\sim 10 \%$ as against $5 \%$ in the general population. ${ }^{16}$

The prevalence of depression and anxiety among people with HIV infection was quite variable across different recent studies. The prevalence rate of depression in HIV patients in different studies varied from $7.2 \%$ to $71.9 \%$ (Table 1 ). The studies were from various countries and had varying sample sizes, different methodologies, and used different depression rating scales or questionnaires.
While treating PLWHA, comorbid anxiety is often missed and not treated. Anxiety is higher among PLWHA than in the general population. In studies conducted across the world, the prevalence of anxiety varied from $4.5 \%$ to $82.3 \%$ (Table 2). Newly diagnosed HIV patients who feel socially stigmatized or are under excessive stress because of their disease had a higher prevalence of anxiety. ${ }^{22}$ The different prevalence rates of anxiety disorders may also depend upon the stage of the illness. ${ }^{23}$ While unipolar depressive disorders are the most common mental disorder among PLWHA, the majority also suffered from comorbid psychiatric disorders, which most frequently included anxiety disorders, dysthymia, and substance use disorder. ${ }^{24}$ 
Table 2 Prevalence of anxiety in patients with HIV

\begin{tabular}{|c|c|c|c|c|}
\hline Location, reference & Scale & $\begin{array}{l}\text { Sample } \\
\text { size }\end{array}$ & $\begin{array}{l}\text { Anxiety } \\
\text { prevalence, \% }\end{array}$ & Associated findings \\
\hline $\begin{array}{l}\text { People's Republic of China, } \\
\text { Lu et } \mathrm{al}^{26}\end{array}$ & SRAS & 102 & 43.13 & $\begin{array}{l}\text { Anxiety and depression were associated with low } \mathrm{CD}^{+} \\
\text {T-lymphocyte counts }\end{array}$ \\
\hline Kenya, Musisi and Kinyanda ${ }^{27}$ & ICD I0 criteria & 82 & 45.6 & $\begin{array}{l}\text { Other comorbid disorders included depression, } \\
\text { somatization, seizures, mania, and HIV-associated } \\
\text { progressive encephalopathy }\end{array}$ \\
\hline Thailand, Nüesch et $\mathrm{al}^{28}$ & HADS & 251 & 16.3 & ART improved mental health and QoL \\
\hline Tanzania, Marwick and Kaaya ${ }^{29}$ & CISR & 220 & 4.5 & $\begin{array}{l}\text { During HIV care, comorbid psychiatric disorders should } \\
\text { be identified and managed }\end{array}$ \\
\hline India, Sivasubramanian et al ${ }^{31}$ & M.I.N.I.; DSM-IV & 150 & 24 & Anxiety associated with low levels of social support \\
\hline Albania, Morrison et al ${ }^{32}$ & $\begin{array}{l}\text { Semistructured } \\
\text { interview }\end{array}$ & 79 & 82.3 & $\begin{array}{l}\text { Anxiety significantly associated with depression, first-line } \\
\text { ART, recent HIV diagnosis, and greater medical and } \\
\text { social needs }\end{array}$ \\
\hline Nigeria, Olagunju et a ${ }^{57}$ & SCAN & 4,000 & 21.7 & $\begin{array}{l}\text { Anxiety was associated with low family support, lack of } \\
\text { employment, and being unmarried }\end{array}$ \\
\hline Canada, Ivanova et $a^{58}$ & $\begin{array}{l}\text { HADS } \\
(\text { HADS-A } \geq I I)\end{array}$ & 361 & $\begin{array}{l}37 \text { had high } \\
\text { anxiety }\end{array}$ & $\begin{array}{l}\text { Anxiety was associated with stigma, ART, and worries } \\
\text { about reproductive health }\end{array}$ \\
\hline India, Agarwal et a ${ }^{35}$ & HADS & 50 & 54 & $46 \%$ of PLWHA had low psychological well-being \\
\hline South Africa, Pappin et $\mathrm{a}^{36}$ & HADS & 716 & 30.6 & $\begin{array}{l}\text { Anxiety was associated with ART side effects, avoidant } \\
\text { coping, and stigma }\end{array}$ \\
\hline India, Chauhan et al ${ }^{43}$ & HADS & 100 & 19 & $\begin{array}{l}\text { Asymptomatic PLWHA had significantly higher } \\
\text { prevalence of alcohol dependence, adjustment disorder, } \\
\text { and sexual dysfunction compared to control subjects }\end{array}$ \\
\hline Italy, Celesia et al ${ }^{59}$ & SRAS & 251 & 47 & $\begin{array}{l}\text { Anxiety was associated with a high number of ART } \\
\text { switches }\end{array}$ \\
\hline Nigeria, Olagunju et al ${ }^{40}$ & SCID-NP & 295 & 8.1 & $\begin{array}{l}\text { Compared to the general population, PLWHA suffer } \\
\text { from more psychiatric disorders }\end{array}$ \\
\hline USA, Parhami et al60 & NA & 7,834 & 16 & $\begin{array}{l}53 \% \text { of the patients had a psychiatric condition, including } \\
\text { mood disorder (23\%) and substance-related disorder } \\
(19 \%)\end{array}$ \\
\hline $\begin{array}{l}\text { People's Republic of China, } \\
\text { Liu et al }{ }^{42}\end{array}$ & SRAS & 320 & 45.6 & $\begin{array}{l}\text { Depression and anxiety in PLWHA could be reduced by } \\
\text { high social support }\end{array}$ \\
\hline Israel, Levy ${ }^{44}$ & STAl & 57 & 18 & $\begin{array}{l}\text { Neurocognitive disturbances and psychiatric illnesses are } \\
\text { common in asymptomatic PLWHA, independent of the } \\
\text { time of being positive, immunological status, viral load, } \\
\text { or treatment received }\end{array}$ \\
\hline South Africa, Nel and Kagee ${ }^{45}$ & BAl & 101 & 28.7 & - \\
\hline $\begin{array}{l}\text { Western Europe and Canada, } \\
\text { Robertson et al }\end{array}$ & HADS & 2,863 & 33.3 & $\begin{array}{l}\text { No significant difference was found between those } \\
\text { receiving combination ART and those not receiving it }\end{array}$ \\
\hline Romania, Largu et $\mathrm{a}^{46}$ & HAS & 146 & $\begin{array}{l}71 \text { ( } 54 \% \text { mild, } \\
14 \% \text { severe, } \\
\text { and } 3 \% \text { very } \\
\text { severe anxiety) }\end{array}$ & $\begin{array}{l}\text { PLWHA were afraid (of death, complications, other } \\
\text { people's reaction to the diagnosis), confused (in terms } \\
\text { of diagnosis, the mode of infection, the future), angry } \\
\text { (against the source of infection, themselves, God), felt } \\
\text { guilty and blamed themselves }\end{array}$ \\
\hline Germany, Kittner et al ${ }^{48}$ & HADS & 80 & $\begin{array}{l}40 \text { (male) and } \\
73 \text { (female) }\end{array}$ & $\begin{array}{l}\text { Guilt for the HIV infection was present in } 36 \% \text { of } \\
\text { PLWHA }\end{array}$ \\
\hline $\begin{array}{l}\text { People's Republic of China, } \\
\text { Sun et al }{ }^{50}\end{array}$ & SRAS & 772 & 49 & $\begin{array}{l}\text { Anxiety was associated with health status, social } \\
\text { support, alcohol consumption, and condom use at the } \\
\text { last sexual contact }\end{array}$ \\
\hline $\begin{array}{l}\text { People's Republic of China, } \\
\text { Qiu et al }{ }^{51}\end{array}$ & GAD-7 & 370 & 30.5 & $\begin{array}{l}\text { Anxiety associated with employment status, sexual } \\
\text { orientation, resident status, emergence of HIV-related } \\
\text { symptoms, and stress }\end{array}$ \\
\hline Ethiopia, Belete et $\mathrm{a}^{22}$ & BAl & 436 & 22.2 & $\begin{array}{l}\text { Being female, perceived stigma, started ART, and } \\
\text { divorced were significantly associated with anxiety }\end{array}$ \\
\hline $\begin{array}{l}\text { Haitian females in USA, } \\
\text { Glémaud et a }{ }^{52}\end{array}$ & NA & 96 & 43 & $\begin{array}{l}\text { I2.5\% of subjects gave a history of abuse; } 34 \% \text { of } \\
\text { subjects had PTSD }\end{array}$ \\
\hline
\end{tabular}


Table 2 (Continued)

\begin{tabular}{|c|c|c|c|c|}
\hline Location, reference & Scale & $\begin{array}{l}\text { Sample } \\
\text { size }\end{array}$ & $\begin{array}{l}\text { Anxiety } \\
\text { prevalence, \% }\end{array}$ & Associated findings \\
\hline Lowther et $\mathrm{al}^{53}$ & $\begin{array}{l}\text { Systematic } \\
\text { review }\end{array}$ & $\begin{array}{l}66 \text { original } \\
\text { studies }\end{array}$ & 28.38 & $\begin{array}{l}\text { Low- and middle-income countries had a higher } \\
\text { prevalence (33.92\%) compared to high-income countries } \\
(25.53 \%)\end{array}$ \\
\hline South Korea, Kee et al ${ }^{54}$ & STAI & 840 & 32 & $\begin{array}{l}\text { Both anxiety and depression were associated with } \\
\text { persistent symptoms, alcohol and tobacco use, and } \\
\text { marital status }\end{array}$ \\
\hline
\end{tabular}

Abbreviations: AIDS, acquired immunodeficiency syndrome; ART, antiretroviral therapy; BAI, Beck Anxiety Inventory; CISR, Clinical Interview Schedule-Revised; DSM, Diagnostic and Statistical Manual of Mental Disorders; GAD-7, Generalized Anxiety Disorder Scale; HADS, Hospital Anxiety and Depression Scale; HAS, Hamilton Anxiety Scale; HIV, human immunodeficiency virus; ICD, International Classification of Diseases; M.I.N.I., Mini-International Neuropsychiatric Interview; PLWHA, persons living with HIVIAIDS; PTSD, post-traumatic stress disorder; QoL, quality of life; SCAN, Schedule for clinical assessment in neuropsychiatry; SCID-NP, Structured Clinical Interview for DSM-IV non-patient; SRAS, Zung Self-Rating Anxiety Scale; STAI, State-Trait Anxiety Inventory; NA, not available.

\section{Risk factors associated with depression among HIV patients}

The occurrence and severity of depression in PLWHA are associated with various factors, which include problems in accepting that they have a deadly illness, HIV-related symptoms, substance use disorders, stigma, stress, disability, lower education, loss of job, lower socioeconomic status, disturbances in body image, social isolation, migration, death of family members, unmarried status, poor relationship with spouse, and frequenting commercial sex workers. ${ }^{4,30,49,55,61,62}$ Logistic regression revealed that the predictors of depression in PLWHA include stress, dissatisfaction with life situation, poor health, belief that all aspects of life are affected by HIV infection, ART, nonadherence, past history of alcohol abuse, and past history of psychiatric treatment. ${ }^{56}$

\section{Stage of illness}

There may be various stages of disease progression in the HIV infection and HIV/AIDS care continuum: diagnosis establishment, contact with HIV medical care, undergoing treatment, at the start of ART, and during adherence to ART. ${ }^{63}$ Asymptomatic stage is less distressing, and a low prevalence may be attributable to this stage of HIV infections. A recent study on asymptomatic HIV patients found relatively low prevalence of only $6 \%$ and $7 \%$, respectively, for depression and anxiety. This study also found significantly increased prevalence of adjustment disorder, alcohol dependence, and sexual dysfunction in asymptomatic PLWHA..$^{43}$ As the illness progresses further and $\mathrm{CD} 4^{+}$cell count declines, the prevalence of depression increases. ${ }^{63,64}$

\section{Gender of the patients}

There are various direct and indirect factors linked to the susceptibility of females in the transmission of HIV/ AIDS. The problem is further compounded with females of developing countries having poor education, health, and hygiene. In one study, female sex workers in Bangladesh reported their inability to convince their sexual partner to have safe sex. ${ }^{65}$ The rates of depression in females in the general population as well as among HIV patients with injectable drug use are higher than those in males. ${ }^{66}$ There are also gender differences in the symptoms of depression. During depressive episodes, females more frequently reported somatic symptoms of anxiety, easy fatigability, hypochondriac symptoms, poor appetite, and insomnia. ${ }^{67-69}$ The presence or absence of these items in any rating scales influences depression ratings across the genders. Two studies focusing on the gender of the patients and psychiatric disorders in PLWHA concluded that HIV-positive females had higher levels of anxiety and depression compared to males. ${ }^{70,71}$ However, two studies found opposite results. ${ }^{72,73}$ The relationship between the gender of the patients and anxiety and depression in PLWHA therefore needs further detailed evaluation.

\section{Depression and HIV infection}

Depression in PLWHA may be a result of CNS involvement by HIV; prior history of mood disorders may not have been present. On the other hand, in an individual newly diagnosed as HIV-positive, the resulting stigma and emotional effects may precipitate an episode or relapse of depression. ${ }^{74}$ A 2-year longitudinal study concluded that the risk of depression in the intermediate term is increased by symptomatic HIV disease but not by HIV infection. However, strong predictors of future vulnerability were either a past history of depression or past history having two or more psychiatric disorders. $^{75}$

\section{Anxiety and HIV infection}

PLWHA may experience anxiety at the time of detection, onset, or progression of HIV infection, ranging across the full spectrum of anxiety disorders. A previous study found 
that anxiety symptoms were common in HIV patients, but the prevalence of syndromal anxiety disorders is similar to that in the general population. ${ }^{76}$ More recent studies have revealed that anxiety and depressive symptoms occur significantly more frequently in PLWHA compared to the general population. ${ }^{54}$ The etiological factors to both anxiety and HIV include alcohol and substance abuse, males having sex with males, or males having a bisexual relationship. ${ }^{77}$ Increased anxiety symptoms in PLWHA were associated with being a former smoker, HIV infection detected within the past year, persistent symptoms presenting for $>7$ days in the past 6 months, ${ }^{54}$ pain, concurrent substance use disorder, minimal family support, and the spouse having AIDS. ${ }^{78}$ In a study based in India, anxiety disorders were detected in 36\% PLWHA, the majority of whom had GAD. The prevalence of anxiety disorders in this study was higher than that found in studies conducted in developed countries. ${ }^{78}$

\section{Panic disorder}

Panic disorder is a frequent comorbid diagnosis with other psychiatric disorders as well as in association with HIV infection. Various studies report that the prevalence of panic disorder in patients with HIV ranged from $11 \%$ to $16 \% .{ }^{4,79-81}$ The prevalence of panic disorder is less in PLWHA with resolved grief compared to those with unresolved grief. ${ }^{82}$

\section{GAD and phobic disorder}

Prevalence of GAD among PLWHA in various studies ranged between $6.5 \%$ and $20 \% .^{4,80,81,83-85}$ Longitudinal studies suggested that the passage of time after the initial diagnosis was associated with a significant decrease in the prevalence of GAD. ${ }^{81}$ Simple phobia was diagnosed in $9 \%$ of 190 PLWHA. ${ }^{83}$

\section{Post-traumatic stress disorder}

In a review of various studies, the prevalence rates of post-traumatic stress disorder (PTSD) were found to vary between $10.4 \%$ and $42.2 \%$ in PLWHA. ${ }^{86}$ The reasons for the occurrence of comorbid PTSD and other anxiety disorders in PLWHA include the trauma of having a potentially fatal illness, stigma related to HIV/AIDS, and the high rates of exposure to traumatic events (physical or sexual assault, the death of a friend or close family member). ${ }^{12,87-93}$

\section{Methodological issues}

The $7.2 \%-71.9 \%$ prevalence for depression and $4.5 \%-82.3 \%$ for anxiety represent significant heterogeneity across various studies. This variance is probably due to the methodological and conceptual factors that differ across studies and the differences in various measuring tools to quantify depression and anxiety (Tables 1 and 2).

There are various methodological issues related to the prevalence studies of anxiety and depression in PLWHA: difficulty in finding homogenous segments of the HIV population; defining depression or anxiety as symptoms or syndromal diagnosis; different diagnostic criteria used such as Diagnostic and Statistical Manual or International Classification of Diseases and their versions; and use of a rating scale that varies from self-reported symptom checklists to clinician-administered psychiatric ratings. ${ }^{20}$ There may be some subgroups such as injection drug users, where a high prevalence of depression is found, independent of the HIV status. ${ }^{94}$ Different studies have also included samples of different age ranges and gender and at different stages of the illness. Some studies enquired for the presence of any depressive symptoms cross-sectional or in the past 2 weeks, or past month, or past year, or lifetime. It is expected that the prevalence of depression will increase as the time frame is lengthened. ${ }^{20}$

\section{Impact}

HIV infection and psychiatric illness are significant related risk factors, as PLWHA suffer from psychiatric symptoms and disorders more frequently than the general population. On the other hand, in people with a severe psychiatric disorder, HIV infection occurs more often than in the general population. Studies indicate that prior psychiatric history and symptomatic HIV disease, but not asymptomatic HIV disease, are predictors of vulnerability for depression. ${ }^{75}$ Various studies and reviews have found a bidirectional association between HIV infection and depression, which involves complex biological and psychosocial interaction. ${ }^{95}$ This leads to two questions: 1) why does HIV infection lead to depression and anxiety; and 2) what does depression and anxiety do to HIV infection.

\section{Why HIV infection leads to depression and anxiety}

Various factors have been identified across studies that can be grouped as psychosocial and biological factors causing depression and anxiety among patients with HIV. Immediately after being diagnosed with HIV, patients show an increase in psychological distress. Adjustment problems were expected among newly diagnosed HIV patients. ${ }^{96}$ However, $\sim 71 \%$ of patients in one study sample were depressed for longer periods than the criterion for adjustment disorder. ${ }^{97}$ The incidence of depression also increases with progression of HIV disease. ${ }^{98,99}$ 


\section{Stigma}

Researchers have identified the stigma of HIV/AIDS as an important factor since stigma is found frequently with HIV/ AIDS and is correlated with depression, anxiety, and other psychosocial problems. ${ }^{100-103}$ Patients with a stigmatizing illness know how other people view them because of their illness. This is called perceived stigma. ${ }^{104}$ Stigmatization leads to restricted social activities, and because of their status, they may start to agree with the negative stereotypes associated with the condition. This process is referred to as internalized stigma, ${ }^{105}$ which ultimately leads to psychosocial distress, depression, and anxiety. ${ }^{101,106,107}$ Stigma has been related to unsafe sex practices, ${ }^{106}$ delay in seeking HIV/AIDS treatment, ${ }^{108}$ poor retention in follow-up, ${ }^{109}$ poor ART adherence, ${ }^{110}$ poor utilization of HIV voluntary counseling and testing services, ${ }^{111}$ and significantly more complaints of anxiety and depression. ${ }^{102}$

\section{Biological model}

It has been suggested that symptoms of anxiety and depression in PLWHA occur because of biological mechanisms. ${ }^{12}$ A recent review ${ }^{113}$ described how HIV can predispose infected individuals to depression by several interrelated mechanisms. These include inducing chronic elevation of cytokines through activation of microglia and astrocytes; decreasing monoaminergic function; inducing neurotoxicity, especially in dopaminergic neurons; and reducing brain-derived neurotrophic factor. These viral pathways interact with psychosocial factors to create the depressive state. ${ }^{113}$ These mechanisms, which may be caused directly by the virus or by the psychological stress related to negative psychosocial impact of HIV diagnosis, may also induce the activation of hypothalamic-pituitary-adrenal axis and the sympathetic nervous system, which activate cellmediated immunity both in the periphery and the CNS. ${ }^{114,115}$ Anxiety and depression may also be associated with systemic immune dysregulation. ${ }^{116}$

\section{Effects of antiretroviral drugs}

Depression and anxiety have also been attributed to antiretroviral drugs. A systematic review revealed that compared to the general population, PLWHA on ART have a higher prevalence of anxiety and depression. ${ }^{53}$ Neuropsychiatric symptoms attributed to antiretroviral drugs (mainly efavirenz) improved significantly following substitution with another drug (eg, nevirapine). ${ }^{117,118}$

\section{What depression and anxiety do to HIV infection}

Depression causes various direct and indirect morbidities, which include suicidal behavior, ${ }^{119}$ increased use of health care facilities, ${ }^{120}$ and poor QoL. ${ }^{80}$ It is important to identify depression among PLWHA, as depression is associated with increased chances of HIV transmission ${ }^{121}$ and ART nonadherence, ${ }^{122-124}$ resulting in failure to suppress viral load ${ }^{125}$ and increased HIV disease progression. ${ }^{126-129}$ There are other mechanisms caused by depression that lead to a faster progression of HIV infection to AIDS, such as elevated cortisol secretion ${ }^{13}$ and HIV replication through an increase in norepinephrine secretion. ${ }^{130}$ Even AIDS-related death, specifically in females, was associated with chronic depression. ${ }^{64,131}$

\section{Depression and disease progression}

HIV infection and the disease progression have altered significantly since the beginning of highly active ART and combination ART (cART). A good outcome depends on the patient's adherence to the medication regimen. Presence of depression is associated with medication nonadherence, resulting in a poor HIV disease outcome. ${ }^{132-134}$ It has been suggested that baseline depression does not influence treatment adherence, as it is affected by incident depression during the treatment period. ${ }^{135}$ This indicates that impaired treatment adherence is due to the acute depression, which occurs as a reactive phenomenon rather than a preexisting or past history, or a predisposition for depression.

\section{Management}

After recognizing, measuring, and understanding depression and anxiety associated with HIV, treating these comorbid disorders is the next focus. It is important to remember that subsyndromal presentation is associated with poor self-care and adverse health outcomes in PLWHA. Therefore, it is also essential to treat sub-syndromal disorders. ${ }^{125}$ Appropriate and adequate management of comorbid depression and anxiety in PLWHA will not only result in symptomatic improvement of a psychiatric disorder but also improve ART adherence and their QoL ${ }^{136,137}$ In addition, improved antiretroviral adherence may reduce depressive symptoms. ${ }^{138}$

\section{Pharmacological intervention}

Anxiolytics, hypnotics, antidepressants, psychostimulants, and hormones have been used for in the treatment of depression and anxiety in PLWHA.

\section{Anxiolytics and hypnotics}

Benzodiazepines (BZDs) are frequently prescribed for anxiety in PLWHA ${ }^{139}$ despite the lack of studies assessing their anti-anxiety effects in PLWHA. ${ }^{136}$ In people at risk of 
habituation, tolerance, and abuse, BZDs are indicated for short periods of time. Also, PLWHA are particularly sensitive to the side effects of BZDs, such as amnesia and paradoxical reactions (disinhibition, confusion, etc). ${ }^{137}$ Both clonazepam and lorazepam lack active metabolites and are safe in terms of drug-drug interactions. These drugs are probably the BZDs of choice for HIV patients receiving antiretrovirals (ARVs). ${ }^{140,141}$ Unlike BZDs, buspirone shows no potential for dependence and tolerance, and sexual dysfunction and weight gain are rare. However, it is metabolized by CYP3A4 and is best avoided in PLWHA receiving protease inhibitors. ${ }^{137,142}$ Efficacy studies of buspirone on PLWHA are lacking. Nonbenzodiazepine hypnotics (eszopiclone, zopiclone, zolpidem, and zaleplon) have low dependence potential and avoid daytime sedation that may occur with BZDs, but are also metabolized by CYP3A4 and should be avoided in PLWHA receiving protease inhibitors. ${ }^{141,143}$

\section{Antidepressants}

\section{Selective serotonin reuptake inhibitors}

Though slightly less effective than tricyclic antidepressants (TCAs), selective serotonin reuptake inhibitors (SSRIs) are better tolerated and therefore, are more suitable for long-term therapy. ${ }^{144}$ Most of the SSRIs have been evaluated in PLWHA. Fluoxetine reduced depressive symptoms significantly compared to placebo. ${ }^{61}$ Significant reduction in depressive symptoms were demonstrated by other SSRIs, but comparative effectiveness of the different SSRIs was yet to be ascertained. ${ }^{137,149}$ Most SSRIs may be used in HIV-positive adults ${ }^{145,146}$ since the most common side effects include anxiety, agitation, akathisia, weight loss, and sexual dysfunction. ${ }^{137}$ However, all SSRIs are metabolized by CYP450 isoenzymes, ${ }^{147}$ so ARVs may affect their plasma levels. To avoid interactions with ARVs, the better options are sertraline, citalopram, and escitalopram. ${ }^{148,149}$ However, it should be kept in mind that the chance of serotonin syndrome is increased when SSRIs are given to PLWHA who are on ART. ${ }^{150}$ Depressed PLWHA who are compliant with SSRIs not only show a reduction in symptoms of depression but also better adherence to highly active ART and improved laboratory parameters. ${ }^{151}$

\section{Comparison of TCAs and SSRIs}

Treatment with both paroxetine and imipramine resulted in significantly greater reduction in depression compared to placebo. ${ }^{152}$ In a double-blind comparison in the treatment of depressed women with advanced HIV disease, the response rate was $63 \%$ and $50 \%$, respectively, for fluoxetine and desipramine. ${ }^{153}$ However, treatment with
TCAs is associated with significantly more side effects. ${ }^{152}$ Considering the fact that dry mouth is a frequent complaint among PLWHA, ${ }^{154}$ TCAs should be used in this population with caution.

\section{Specific issues with newer antidepressants}

Nefazodone is useful in treating depression in PLWHA. ${ }^{155}$ However, nefazodone-induced hepatitis is a known entity, and hence it should be used with care in PLWHA because of the frequent occurrence of viral hepatitis. Mirtazapine is also an effective antidepressant with the added benefit of decreasing nausea and increasing weight, and can be useful in HIV wasting disease. ${ }^{156}$ Venlafaxine has minimal interaction with CYP450 enzymes, reducing the chances of interaction with antiretroviral drugs; however, when used alongside ritonavir, its dose should be decreased. ${ }^{157}$ The metabolism of bupropion is interfered by ritonavir, efavirenz, and nelfinavir. ${ }^{158,159} \mathrm{~A}$ small study reported good tolerance of reboxetine in HIV patients. ${ }^{160}$

\section{Psychostimulants}

In an observational study, depressed PLWHA were randomly assigned to two groups and treated with either desipramine or methylphenidate. Treatment response was observed in $40 \%$ and $43 \%$ of subjects, respectively. ${ }^{161}$ A similar study reported that $73 \%$ of those assigned to dextroamphetamine responded to treatment. ${ }^{162}$ A specific indication for psychostimulants is neglect of self-care and nutrition in advanced HIV patients. ${ }^{161,162}$

\section{Hormonal therapies}

Testosterone is reduced in HIV infection, and this may lead to anorexia, anergia, depression, and sexual dysfunction. Based on this hypothesis, hormonal therapies have been advocated to treat depression in PLWHA with some success. ${ }^{163}$ However, this type of therapy is likely to be useful in PLWHA with decreased testosterone level.

\section{Nonpharmacological interventions}

Various techniques and interventions employed in a depressed population were studied in PLWHA. The major interventions employed were cognitive behavior therapy (CBT), interpersonal therapy (IPT), supportive psychotherapy, cognitivebehavioral-oriented group psychotherapy, experiential group psychotherapy, cognitive-behavioral stress management (CBSM), stress management interventions, cognitive remediation therapy, mindfulness-based therapy, and aerobic and resistance exercise. 


\section{Cognitive behavior therapy}

There is considerable evidence in the form of randomized controlled studies, meta-analysis, and systematic analysis attesting the efficacy of CBT in treating anxiety and depressive disorders in PLWHA. ${ }^{164-166} \mathrm{~A}$ study by Lee et $\mathrm{l}^{164}$ evaluated the feasibility and effectiveness of group CBT in combination with medication in 13 patients with HIV and depression. The authors found an overall positive response in terms of improvement in depression, and cognitive restructuring was the most helpful psychotherapeutic process of CBT. In a meta-analysis of 15 controlled trials, significant effects were found for improving symptoms of depression $(d=0.33)$, anxiety $(d=0.30)$, anger $(d=1.00)$, and stress $(d=0.43) .{ }^{165}$ Similarly, a recent systemic review including 2,173 participants from 20 studies suggested that cognitive-behavioral intervention may be effective in the treatment of depression and anxiety in individuals living with HIV/AIDS. Effect sizes ranged from 0.02 to 1.02 for depression and 0.04 to 0.70 for anxiety. ${ }^{166}$

\section{Interpersonal therapy}

A randomized clinical trial reported that IPT resulted in significantly lower scores on the Hamilton Rating Scale for Depression (HAM-D) and the Beck Depression Inventory (BDI) compared to supportive psychotherapy. ${ }^{167}$ Another randomized controlled trial involved randomly assigning 101 PLWHA with clinical depression and score $\geq 15$ on the HAM-D to various treatment modalities. Results indicated that a significantly greater reduction in HAM-D scores occurred after IPT and supportive psychotherapy plus imipramine compared to CBT and supportive psychotherapy without imipramine. ${ }^{168}$

\section{Supportive psychotherapy}

Supportive psychotherapy was primarily based on teaching coping skills. A comparative study of CBT and supportive therapy reported clinically significant changes in depression in both groups, which were maintained at follow-up after 3 months. An important finding was that the occurrence of unprotected anal intercourse was reduced after supportive therapy. ${ }^{167}$

\section{Cognitive-behavioral-oriented group psychotherapy}

Two small studies found cognitive-behavioral-oriented group psychotherapy to be effective in improving psychosocial adjustment and reducing psychological distress in PLWHA. ${ }^{169,170}$

\section{Experiential group psychotherapy}

A randomized study comparing the effects of experiential group psychotherapy and cognitive-behavioral group psychotherapy on asymptomatic homosexual PLWHA concluded that, while both therapies reduced psychological distress, there was no significant difference between the two therapies. ${ }^{170}$

\section{Cognitive-behavioral stress management}

A few studies have reported significant reductions in depression, ${ }^{171-175}$ improved immune control of latent HSV-2 virus, ${ }^{174}$ and reduced urinary cortisol levels after CBSM. ${ }^{174,175}$ The reduction in depression was directly related to reduction in cortisol levels in urine. ${ }^{174,175} \mathrm{CBSM}$ training of PLWHA taking cART reduces anxiety and depression ${ }^{176,177}$ and improves global psychological functioning ${ }^{180}$ and QoL $\mathrm{L}^{176,177}$ but does not improve surrogate markers of HIV-1 and self-reported adherence to therapy. ${ }^{176}$

\section{Stress management interventions}

A meta-analysis revealed that, in PLWHA, stress management resulted in significant improvements in anxiety, depression, distress, fatigue, and QoL, but had no effect on immune function ( $\mathrm{CD}^{+}$counts and viral load) or hormone functions, indicating the need for further studies. ${ }^{178} \mathrm{~A}$ recent study concluded that, while both group stress management and group CBT were effective in PLWHA, the former was more effective than the latter to decrease depression and anxiety. ${ }^{179}$

\section{Cognitive remediation therapy}

In addition to anxiety and depression, PLWHA continue to have cognitive impairments despite receiving cART. These cognitive and emotional impairments adversely affect occupational and driving performance, contribute to poor emotional processing, increase cognitive complaints, reduce QoL, and increase caregiver burden. Speed-of-processing training, a type of cognitive remediation therapy, may help to improve cognitive performance on measures of visual attention, speed of processing, and timed-task performances. A few studies also suggest that speed-of-processing training could also improve mood functions (depression and anxiety). The benefits of the improvement in these cognitive and emotional systems are a decrease or slowing in cognitive decline along with the potential to protect against clinically significant depressive symptoms. Further investigation into the benefits of this type of training as a behavioral adjunct for the pharmacologically burdened HIV population is needed. ${ }^{180}$ 


\section{Mindfulness-based therapy}

Mindfulness-based treatment improves the well-being and QoL of PLWHA. In addition, it contributes to enhanced immunity, telomerase activity, and plasma levels of serotonin and melatonin. At the same time, it diminishes autonomic nervous system reactivity. ${ }^{181}$

\section{Aerobic and resistance exercise}

Exercise produces beneficial physiological changes and also reduces depression and anxiety in PLWHA. ${ }^{182}$

\section{Conclusion}

There is enormous variation in the reported prevalence rates of depression, which ranges from $16 \%$ to $72 \%$, and in the prevalence for anxiety, which ranges from $16 \%$ to $47 \%$, among HIV patients. Various factors associated with and causative for this wide variation across studies include sample composition, diagnostic issues, different rating scales, gender of the patients, staging of HIV illness, etc. Moreover, depression increases the morbidity of HIV by poor adherence to treatment and various other significant mechanisms. Early identification and effective management of these disorders improves the QoL and adherence to ARV in PLWHA. Different treatment modalities including pharmacological and nonpharmacological psychotherapies have been used for the management of depression and anxiety in PLWHA. BZDs are indicated for short periods of time. Clonazepam and lorazepam are safe in terms of drug-drug interactions and may be preferred. SSRI are safer than TCAs. While differences in the efficacy of various SSRIs have not been established, to avoid interactions with ARVs, the better options are sertraline, citalopram, and escitalopram. Nonpharmacological therapies, including various psychotherapies and aerobic and resistance exercises, are effective in treating depression among PLWHA. However, definitive evidence to decide which nonpharmacological intervention is most beneficial for the management of depression in PLWHA is still awaited.

\section{Disclosure}

The authors report no conflicts of interest in this work.

\section{References}

1. World Health Organization. WHO Case Definitions of HIV for Surveillance and Revised Clinical Staging and Immunological Classification of HIV-Related Disease in Adults and Children. Geneva: World Health Organization; 2007:8.

2. WHO [webpage on the Internet]. Health Topics. HIV/AIDS Online. Geneva, World Health Organization, 2016. Available from: http://www. who.int/topics/hiv_aids/en/. Accessed February 24, 2016.
3. Bravo P, Edwards A, Rollnick S, Elwyn G. Tough decisions faced by people living with HIV: a literature review of psychosocial problems. AIDS Rev. 2010;12(2):76-88.

4. Bing EG, Burnam MA, Longshore D, Fleishman JA, Sherbourne CD, London AS. Psychiatric disorders and drug use among human immunodeficiency virus-infected adults in the United States. Arch Gen Psychiatry. 2001;58:721-728.

5. Robertson K, Bayon C, Molina JM, et al. Screening for neurocognitive impairment, depression, and anxiety in HIV-infected patients in Western Europe and Canada. AIDS Care. 2014;26(12):1555-1561.

6. Andrinopoulos K, Clum G, Murphy DA, et al; Adolescent Medicine Trials Network for HIVAIDS Interventions. Health related quality of life and psychosocial correlates among HIV-infected adolescent and young adult women in the US. AIDS Educ Prev. 2011;23:367-381.

7. Peter E, Kamath R, Andrews T, Hegde BM. Psychosocial determinants of health-related quality of life of people living with HIV/AIDS on antiretroviral therapy at Udupi District, Southern India. Int J Prev Med. 2014;5(2):203-209.

8. Reisner SL, Mimiaga MJ, Skeer M, Perkovich B, Johnson CV, Safren SA. A review of HIV antiretroviral adherence and intervention studies among HIV-infected youth. Top HIV Med. 2009;17(1):14-25.

9. Psaros C, O'Cleirigh C, Bullis JR, Markowitz SM, Safren SA. The influence of psychological variables on health-related quality of life among HIV-positive individuals with a history of intravenous drug use. J Psychoactive Drugs. 2013;45(4):304-312.

10. Sin NL, DiMatteo MR. Depression treatment enhances adherence to antiretroviral therapy: a meta-analysis. Ann Behav Med. 2014;47(3):259-269.

11. Meade CS, Sikkema KJ. HIV risk behavior among adults with severe mental illness: a systematic review. Clin Psychol Rev. 2005;25(4):433-457.

12. Simoni JM, Safren SA, Manhart LE, et al. Challenges in addressing depression in HIV research: assessment, cultural context, and methods. AIDS Behav. 2011;15(2):376-388.

13. Schuster R, Bornovalova M, Hunt E. The influence of depression on the progression of HIV: direct and indirect effects. Behav Modif. 2012;36(2):123-145.

14. Phillips KD, Sowell RL, Rojas M, Tavakoli A, Fulk LJ, Hand GA. Physiological and psychological correlates of fatigue in HIV disease. Biol Res Nurs. 2004;6(1):59-74.

15. Dubé B, Benton T, Cruess DG, Evans DL. Neuropsychiatric manifestations of HIV infection and AIDS. $J$ Psychiatry Neurosci. 2005;30:237-246.

16. Ciesla JA, Roberts JE. Meta-analysis of the relationship between HIV infection and risk for depressive disorders. Am J Psychiatry. 2001;158:725-730.

17. Elenga N, Georger-Sow MT, Messiaen T, et al. Incidence and predictive factors of depression among patients with HIV infection in Guadeluope: 1988-2009. Int J STD AIDS. 2014;25(8):559-563.

18. Nacher M, Adriouch L, Godard Sebillotte C, et al. Predictive factors and incidence of anxiety and depression in a cohort of HIV-positive patients in French Guiana. AIDS Care. 2010;22(9):1086-1092.

19. Ohaeri JU, Jegede RO. Depression and the general medical practitioner in Nigeria. Medicare. 1991;6:7-11.

20. Rabkin JG. HIV and depression: 2008 review and update. Curr HIV/ AIDS Rep. 2008;5(4):163-171.

21. Willard S, Holzemer WL, Wantland DJ, et al. Does "asymptomatic" mean without symptoms for those living with HIV infection? AIDS Care. 2009;21(3):322-328.

22. Belete A, Andaregie G, Tareke M, Birhan T, Azale T. Prevalence of anxiety and associated factors among people living with HIV/AIDS at Debretabor general hospital anti retro viral clinic Debretabor, Amhara, Ethiopia, 2014. Am J Psychiatry Neurosci. 2014;2(6):109-114.

23. Perkins DO, Stern RA, Golden RN, Murphy C, Naftolowitz D, Evans DL. Mood disorders in HIV infection. Prevalence and risk factors in a non epicenter of the AIDS epidemic. Am J Psychiatry. 1994;15:233-236. 
24. Gaynes BN, O’Donnell J, Nelson E, et al. Psychiatric comorbidity in depressed HIV-infected individuals: common and clinically consequential. Gen Hosp Psychiatry. 2015;37(4):277-282.

25. Sale S, Gadanya M. Prevalence and factors associated with depression in HIV/AIDS patients aged 15-25 years at Aminu Kano Teaching Hospital, Nigeria. J Child Adolesc Ment Health. 2008;20(2):95-99.

26. Lu SH, Tang XP, Deng XL, Chen WL, Hu RX. Relationship between psychological distress and T lymphocyte in HIV/AIDS patients. Zhonghua Shi Yan He Lin Chuang Bing Du Xue Za Zhi. 2009;23(1): 23-25.

27. Musisi S, Kinyanda E. Emotional and behavioural disorders in HIV seropositive adolescents in urban Uganda. East Afr Med J. 2009;86(1):16-24.

28. Nüesch R, Gayet-Ageron A, Chetchotisakd P, et al; STACCATO Study Group. The impact of combination antiretroviral therapy and its interruption on anxiety, stress, depression and quality of life in Thai patients. Open AIDS J. 2009;3:38-45.

29. Marwick KF, Kaaya SF. Prevalence of depression and anxiety disorders in HIV-positive outpatients in rural Tanzania. AIDS Care. 2010;22(4):415-419.

30. Clarke TR, Gibson RC, Barrow G, Abel WD, Barton EN. Depression among persons attending a HIV/AIDS outpatient clinic in Kingston, Jamaica. West Indian Med J. 2010;59(4):369-373.

31. Sivasubramanian M, Mimiaga MJ, Mayer KH, et al. Suicidality, clinical depression, and anxiety disorders are highly prevalent in men who have sex with men in Mumbai, India: findings from a community-recruited sample. Psychol Health Med. 2011;16(4):450-462.

32. Morrison SD, Banushi VH, Sarnquist C, et al. Levels of self-reported depression and anxiety among HIV-positive patients in Albania: a crosssectional study. Croat Med J. 2011;52(5):622-628.

33. Bhatia R, Hartman C, Kallen MA, Graham J, Giordano TP. Persons newly diagnosed with HIV Infection are at high risk for depression and poor linkage to care. AIDS Behav. 2011;15(6):1161-1170.

34. Kinyanda E, Hoskins S, Nakku J, Nawaz S, Patel V. Prevalence and risk factors of major depressive disorder in HIV/AIDS as seen in semi-urban Entebbe district, Uganda. BMC Psychiatry. 2011;11:205.

35. Agrawal M, Srivastava K, Goyal S, Chaudhury S. Psychosocial correlates of human immunodeficiency virus infected patients. Ind Psychiatry J. 2012;21(1):55-60.

36. Pappin M, Wouters E, Booysen FL. Anxiety and depression amongst patients enrolled in a public sector antiretroviral treatment programme in South Africa: a cross-sectional study. BMC Public Health. 2012;12:244.

37. L'akoa RM, Noubiap JJ, Fang Y, Ntone FE, Kuaban C. Prevalence and correlates of depressive symptoms in HIV-positive patients: a crosssectional study among newly diagnosed patients in Yaoundé, Cameroon. BMC Psychiatry. 2013;13:228.

38. Su X, Lau JT, Mak WW, et al. Prevalence and associated factors of depression among people living with HIV in two cities in China. J Affect Disord. 2013;149:108-115.

39. Talukdar A, Ghosal MK, Sanyal D, et al. Determinants of quality of life in HIV-infected patients receiving highly active antiretroviral treatment at a medical college ART center in Kolkata, India. J Int Assoc Provid AIDS Care. 2013;12(4):284-290.

40. Olagunju AT, Ogundipe OA, Erinfolami AR, Akinbode AA, Adeyemi JD. Toward the integration of comprehensive mental health services in HIV care: an assessment of psychiatric morbidity among HIV-positive individuals in sub-Saharan Africa. AIDS Care. 2013;25(9):1193-1198.

41. Song JY, Lee JS, Seo YB, et al. Depression among HIV-infected patients in Korea: assessment of clinical significance and risk factors. Infect Chemother. 2013;45(2):211-216.

42. Liu L, Pang R, Sun W, et al. Functional social support, psychological capital, and depressive and anxiety symptoms among people living with HIV/AIDS employed full-time. BMC Psychiatry. 2013;13:324.

43. Chauhan VS, Chaudhury S, Sudarsanan S, Srivastava K. Psychiatric morbidity in asymptomatic human immunodeficiency virus patients. Ind Psychiatry J. 2013;22(2):125-130.
44. Levy I, Goldstein A, Fischel T, Maor Y, Litachevsky V, Rahav G. Neurocognitive disturbances and psychiatric disorders among patients living with HIV-1 positive in Israel. Harefuah. 2013;152(4): 196-199.

45. Nel A, Kagee A. The relationship between depression, anxiety and medication adherence among patients receiving antiretroviral treatment in South Africa. AIDS Care. 2013;25(8):948-955.

46. Largu MA, Dorobăț CM, Prisacariu L, Nicolau C, Astărăstoae V, Manciuc C. The psycho-emotional profile of the HIV-positive naïve patient. Rev Med Chir Soc Med Nat Iasi. 2014;118(3):733-737.

47. Kim MH, Mazenga AC, Devandra A, et al. Prevalence of depression and validation of the Beck Depression Inventory-II and the Children's Depression Inventory-Short amongst HIV-positive adolescents in Malawi. J Int AIDS Soc. 2014;17:18965.

48. Kittner JM, Brokamp F, Thomaidis T, et al. Disclosure and experienced social support are not related to anxiety or depression in a German HIV patient cohort. Infect Chemother. 2014;46(2):77-83.

49. Bhatia MS, Munjal S. Prevalence of depression in people living with HIV/AIDS undergoing ART and factors associated with it. J Clin Diagn Res. 2014;8(10):1-4.

50. Sun W, Wu M, Qu P, Lu C, Wang L. Psychological well-being of people living with HIV/AIDS under the new epidemic characteristics in China and the risk factors: a population-based study. Int J Infect Dis. 2014;28:147-152.

51. Qiu Y, Luo D, Cheng R, et al. Emotional problems and related factors in patients with HIV/AIDS. Zhong Nan Da Xue Xue Bao Yi Xue Ban. 2014;39(8):835-841.

52. Glémaud M, Illa L, Echenique M, et al. Abuse and mental health concerns among HIV-infected Haitian women living in the United States. J Assoc Nurses AIDS Care. 2014;25(1 suppl):S62-S69.

53. Lowther K, Selman L, Harding R, Higginson IJ. Experience of persistent psychological symptoms and perceived stigma among people with HIV on antiretroviral therapy (ART): a systematic review. Int J Nurs Stud. 2014;51(8):1171-1189.

54. Kee MK, Lee SY, Kim NY, et al. Anxiety and depressive symptoms among patients infected with human immunodeficiency virus in South Korea. AIDS Care. 2015;27(9):1174-1182.

55. Nomoto SH, Longhi RM, de Barros BP, Croda J, Ziff EB, Castelon Konkiewitz E. Socioeconomic disadvantage increasing risk for depression among recently diagnosed HIV patients in an urban area in Brazil: cross-sectional study. AIDS Care. 2015;5:1-7.

56. Slot M, Sodemann M, Gabel C, Holmskov J, Laursen T, Rodkjaer L. Factors associated with risk of depression and relevant predictors of screening for depression in clinical practice: a cross-sectional study among HIV-infected individuals in Denmark. HIV Med. 2015;16(7):393-402.

57. Olagunju AT, Adeyemi JD, Ogbolu RE, Campbell EA. A study on epidemiological profile of anxiety disorders among people living with HIV/AIDS in a sub-Saharan Africa HIV clinic. AIDS Behav. 2012;16(8):2192-2197.

58. Ivanova EL, Hart TA, Wagner AC, Aljassem K, Loutfy MR. Correlates of anxiety in women living with HIV of reproductive age. AIDS Behav. 2012;16(8):2181-2191.

59. Celesia BM, Nigro L, Pinzone MR, et al. High prevalence of undiagnosed anxiety symptoms among HIV-positive individuals on cART: a cross-sectional study. Eur Rev Med Pharmacol Sci. 2013;17(15):2040-2046.

60. Parhami I, Fong TW, Siani A, Carlotti C, Khanlou H. Documentation of psychiatric disorders and related factors in a large sample population of HIV-positive patients in California. AIDS Behav. 2013;17(8):2792-2801.

61. Zisook S, Peterkin J, Goggin KJ, Sledge P, Atkinson JH, Grant I. Treatment of major depression in HIV-seropositive men. HIV Neurobehavioral Research Center Group. J Clin Psychiatry. 1998;59: 217-224.

62. Asch SM, Kilbourne AM, Gifford AL, et al. Under diagnosis of depression in HIV. J Gen Intern Med. 2003;18:450-460. 
63. Burack JH, Barrett DC, Stall RD, Chesney MA, Ekstrand ML, Coates TJ Depressive symptoms and CD4 lymphocyte decline among HIV-infected men. JAMA. 1993;270:2568-2573.

64. Ickovics JR, Hamburger ME, Vlahov D, et al. Mortality, CD4 cell count decline and depressive symptoms among HIV-seropositive women: longitudinal analysis from the HIV Epidemiology Research Study. JAMA. 2001;285:1466-1474.

65. Habib SE. AIDS, Sex Work and Gender: Researching Female Sex Workers in Bangladesh. In: Hossain KT, Imam MH, Habib SE, editors. Women Gender and Discrimination. Rajshahi: Higher Education Link Programme; 2004:155-170.

66. Valverdee EE, Purcell D, Waldrop-Valverfe D, et al. Correlates of depression among HIV-positive women and men who inject drugs. J Acquir Immune Defic Syndr. 2007;46(supp1 2):S96-S100.

67. Frank E, Carpenter LL, Kupfer DJ. Sex differences in recurrent depression: are there any that are significant? Am J Psychiatry. 1988; 145:41-45.

68. Young EA. Glucocorticoid cascade hypothesis revisited: role of gonadal steroids. Depression. 1990;3:20-27.

69. Silverstein B. Gender difference in the prevalence of clinical depression: the role played by depression associated with somatic symptoms. Am J Psychiatry. 1999;156:480-482.

70. Ofovwe CE, Ofovwe C. Psychological disorders among human immunodeficiency virus-infected adults in southern Nigeria. Afr J Reprod Health. 2013;17(4 Spec No):177-182.

71. Saadat M, Behboodi ZM, Saadat E. Comparison of depression, anxiety, stress, and related factors among women and men with human immunodeficiency virus infection. J Hum Reprod Sci. 2015;8(1): $48-51$.

72. Lopes M, Olfson M, Rabkin J, et al. Gender, HIV status, and psychiatric disorders: results from the national epidemiologic study on alcohol and related conditions. J Clin Psychiatry. 2012;73(3):384-391.

73. Jallow A, Ljunggren G, Wändell P, Carlsson AC. Prevalence, incidence, mortality and co-morbidities amongst human immunodeficiency virus (HIV) patients in Stockholm County, Sweden - the Greater Stockholm HIV Cohort Study. AIDS Care. 2015;27(2):142-149.

74. Owe-Larsson B, Sall L, Salamon E, Allgulander C. HIV infection and psychiatric illness. Afr J Psychiatry (Johannesbg). 2009;12: $115-128$.

75. Atkinson JH, Heaton RK, Patterson TL, et al. Two-year prospective study of major depressive disorder in HIV-infected men. JAffect Disord. 2008;108(3):225-234.

76. Sewell MC, Goggin KJ, Rabkin JG, Ferrando SJ, McElhiney MC, Evans S. Anxiety syndromes and symptoms among men with AIDS: a longitudinal controlled study. Psychosomatics. 2000;41: 294-300

77. Ferrando S, Goggin K, Sewell M, Evans S, Fishman B, Rabkin J. Substance use disorders in gay/bisexual men with HIV and AIDS Am J Addict. 1998;7:51-60.

78. Chandra PS, Ravi V, Desai A. Anxiety and depression among HIVinfected heterosexuals- a report from India. J Psychosom Res. 1998;45:401-409.

79. Orlando M, Burnam A, Beckman R, et al. Re-estimating the prevalence of psychiatric disorders in a nationally representative sample of persons receiving care for HIV: results from the HIV Cost and Services Utilization Study. Int J Methods Psychiatr Res. 2001;11(2):75-82.

80. Sherbourne CD, Hays RD, Fleishman JA, et al. Impact of psychiatric conditions on health-related quality of life in persons with HIV infection. Am J Psychiatry. 2000;157:248-254.

81. Tsao JC, Dobalian A, Naliboff BD. Panic disorder and pain in a national sample of persons living with HIV. Pain. 2004;109:172-180.

82. Summers J, Zisook S, Atkinson JH, et al. Psychiatric morbidity associated with acquired immunodeficiency syndrome-related grief resolution. J Nerv Ment Dis. 1995;183:384-389.

83. Haller DL, Miles DR. Suicidal ideation among psychiatric patients with HIV: psychiatric morbidity and quality of life. AIDS Behav. 2003;7(2):101-108.
84. Tucker JS, Burnam MA, Sherbourne CD, Kung FY, Gifford AL. Substance use and mental health correlates of nonadherence to antiretroviral medications in a sample of patients with human immunodeficiency virus infection. Am J Med. 2003;114:573-580.

85. Wilkins JW, Robertson KR, Snyder CR, Robertson WK, van der Horst C, Hall CD. Implications of self-reported cognitive and motor dysfunctions in HIV-positive patients. Am J Psychiatry. 1991;148(5): 641-643.

86. Coughlin SS. Anxiety and depression: linkages with viral diseases. Public Health Rev. 2012;34(2):92.

87. Katz S, Nevid JS. Risk factors associated with posttraumatic stress disorder symptomatology in HIV-infected women. AIDS Patient Care STDS. 2005;19:110-120.

88. Soller M, Kharrazi N, Prentiss D, et al. Utilization of psychiatric services among low-income HIV-infected patients with psychiatric comorbidity. AIDS Care. 2011;23:1351-1359.

89. Martin L, Kagee A. Lifetime and HIV-related PTSD among persons recently diagnosed with HIV. AIDS Behav. 2011;15:125-131.

90. Radcliffe J, Fleisher CL, Hawkins LA, et al. Posttraumatic stress and trauma history in adolescents and young adults with HIV. AIDS Patient Care STDS. 2007;21:501-508.

91. Brief DJ, Bollinger AR, Vielhauer MJ, et al. Understanding the interface of HIV, trauma, post-traumatic stress disorder, and substance use and its implications for health outcomes. AIDS Care. 2004;16:S97-S120.

92. Beckerman NL, Auerbach C. PTSD and HIV in women: the role of gender in this dual diagnosis. Women Health. 2011;51:497-510.

93. Theuninck AC, Lake N, Gibson S. HIV-related posttraumatic stress disorder: investigating the traumatic events. AIDS Patient Care STDS. 2010;24:485-491.

94. Chander G, Himelhoch S, Moore R. Substance abuse and psychiatric disorder in HIV-positive patients. Drugs. 2006;66:769-789.

95. Nanni MG, Caruso R, Mitchell AJ, Meggiolaro E, Grassi L. Depression in HIV infected patients: a review. Curr Psychiatry Rep. 2015;17(1):530.

96. Lyketsos CG, Hanson A, Fishman M, McHugh PR, Treisman GJ. Screening for psychiatric morbidity in a medical outpatient clinic for HIV infection: the need for a psychiatric presence. Int J Psychiatry Med. 1994;24(2):103-113.

97. Savetsky JB, Sullivan LM, Clarke J, Stein MD, Samet JH Evolution of depressive symptoms in human immunodeficiency virus-infected patients entering primary care. J Nerv Ment Dis. 2001;189(2):76-83.

98. Hinkin CH, Castellon SA, Atkinson JH, Goodkin K. Neuropsychiatric aspects of HIV infection among older adults. $J$ Clin Epidemiol. 2001;54(suppl 1):S44-S52.

99. de Ronchi D, Faranca I, Forti P, et al. Development of acute psychotic disorders and HIV-1 infection. Int J Psychiatry Med. 2000;30(2):173-183.

100. Khan N, Loewenson R. Guidelines for Reducing Stigma and Discrimination and Enhancing Care and Support for People Living with HIV and AIDS. Harare: Training and Research Support Centre; South African Network of AIDS Service Organizations and European Commission; 2005.

101. Li L, Lee SJ, Thammawijaya P, Jiraphongsa C, Rotheram-Borus MJ. Stigma, social support, and depression among people living with HIV in Thailand. AIDS Care. 2009;21(8):1007-1013.

102. Kamen C, Arganbright J, Kienitz E, et al. HIV-related stigma: implications for symptoms of anxiety and depression among Malawian women. Afr J AIDS Res. 2015;14(1):67-73.

103. Liu Y, Gong H, Yang G, Yan J. Perceived stigma, mental health and unsafe sexual behaviors of people living with HIV/AIDS. Zhong Nan Da Xие Xие Bao Yi Xue Ban. 2014;39(7):658-663.

104. Rao D, Choi SW, Victorson D, et al. Measuring stigma across neurological conditions: the development of the stigma scale for chronic illness (SSCI). Qual Life Res. 2009;18(5):585-595.

105. Corrigan P, Watson A, Barr L. The self-stigma of mental illness: implications for self esteem and self efficacy. J Soc Clin Psychol. 2006;25(9):875-884. 
106. Hatzenbuehler ML, O’Cleirigh C, Mayer KH, Mimiaga MJ, Safren SA. Prospective associations between HIV-related stigma, transmission risk behaviors, and adverse mental health outcomes in men who have sex with men. Ann Behav Med. 2011;42(2):227-234.

107. Shacham E, Rosenburg N, Önen NF, Donovan MF, Overton ET. Persistent HIV-related stigma among an outpatient US clinic population. Int J STD AIDS. 2015;26(4):243-250.

108. Abaynew Y, Deribew A, Deribe K. Factors associated with late presentation to HIV/AIDS care in South Wollo ZoneEthiopia: a case-control study. AIDS Res Ther. 2011;8:8.

109. Assefa Y, Van Damme W, Mariam DH, Kloos H. Toward universal access to HIV counseling and testing and antiretroviral treatment in Ethiopia: looking beyond HIV testing and ART initiation. AIDS Patient Care STDS. 2010;24(8):521-525.

110. Biadgilign S, Deribew A, Amberbir A, Deribe K. Barriers and facilitators to antiretroviral medication adherence among HIV-infected paediatric patients in Ethiopia: a qualitative study. SAHARA J. 2009;6(4):148-154.

111. Maedot P, Haile A, Lulseged S, Belachew A. Determinants of vct uptake among pregnant women attending two ANC clinics in Addis Ababa City: unmatched case control study. Ethiop Med J. 2007;45(4):335-342.

112. Maes M, Kubera M, Obuchowiczwa E, Goehler L, Brzeszcz J. Depression's multiple comorbidities explained by (neuro)inflammatory and oxidative and nitrosative stress pathways. Neuro Endocrinol Lett. 2011;32(1):7-24.

113. Del Guerra FB, Fonseca JL, Figueiredo VM, Ziff EB, Konkiewitz EC. Human immunodeficiency virus-associated depression: contributions of immuno-inflammatory, monoaminergic, neurodegenerative, and neurotrophic pathways. J Neurovirol. 2013;19(4):314-327.

114. Leonard BE. The concept of depression as a dysfunction of the immune system. Curr Immunol Rev. 2010;6(3):205-212.

115. Krishnadas R, Cavanagh J. Depression: an inflammatory illness? J Neurosurg Psychiatry. 2012;83(5):495-502.

116. McGuire JL, Kempen JH, Localio R, Ellenberg JH, Douglas SD. Immune markers predictive of neuropsychiatric symptoms in HIVinfected youth. Clin Vaccine Immunol. 2015;22(1):27-36.

117. Mothapo KM, Schellekens A, van Crevel R, et al. Improvement of depression and anxiety after discontinuation of long-term efavirenz treatment. CNS Neurol Disord Drug Targets. 2015;14(6):811-818.

118. Pedrol E, Llibre JM, Tasias M, et al. Outcome of neuropsychiatric symptoms related to an antiretroviral drug following its substitution by nevirapine: the RELAX study. HIV Med. 2015;16(10):628-634.

119. Wulsin LR, Vaillant GE, Wells VE. A systematic review of the mortality of depression. Psychosom Med. 1999;61:6-17.

120. Katon WJ. Clinical and health services relationships between major depression, de pressive symptoms, and general medical illness. Biol Psychiatry. 2003;54:216-226.

121. Treisman G, Angelino A. Interrelation between psychiatric disorders and the prevention and treatment of HIV infection. Clin Infect Dis. 2007;45(suppl 4):S313-S317.

122. Sternhell PS, Corr MJ. Psychiatric morbidity and adherence to antiretroviral medication in patients with HIV/AIDS. Aust NZJ Psychiatry. 2002;36:528-533.

123. Adejumo O, Oladeji B, Akpa O, et al. Psychiatric disorders and adherence to antiretroviral therapy among a population of HIV-infected adults in Nigeria. Int J STD AIDS. Epub Sep 182015.

124. Springer SA, Dushaj A, Azar MM. The impact of DSM-IV mental disorders on adherence to combination antiretroviral therapy among adult persons living with HIV/AIDS: a systematic review. AIDS Behav. 2012;16(8):2119-2143.

125. Paterson DL, Swindells S, Mohr J, et al. Adherence to protease inhibitor therapy and outcomes in patients with HIV infection. Ann Intern Med. 2000; $133: 21-30$

126. Leserman J. HIV disease progression: depression, stress, and possible mechanisms. Biol Psychiatry. 2003;54:295-306.
127. Evans DL, Ten Have TR, Douglas SD, et al. Association of depression with viral load, CDS T lymphocytes and natural killer cells in women with HIV infection. Am J Psychiatry. 2002;159:1752-1759.

128. Ironson G, Balbin E, Solomon G, et al. Relative preservation of natural killer cell cytotoxicity and number in healthy AIDS patients with low CD4 cell counts. AIDS. 2001;15(16):2065-2073.

129. Cruess DG, Douglas SD, Petitto JM, et al. Association of resolution of major depression with increased natural killer cell activity among HIV-seropositive women. Am J Psychiatry. 2005;162(11): 2125-2130.

130. Grossman F, Potter WZ. Catecholamines in depression: a cumulative study of urinary norepinephrine and its major metabolites in unipolar and bipolar depressed patients versus healthy volunteers at the NIMH. Psychiatry Res. 1999;87:21-27.

131. Cook JA, Grey D, Burke J, et al. Depressive symptoms and AIDSrelated mortality among a multisite cohort of HIV-positive women. Am J Public Health. 2004;94:1133-1140.

132. Ammassari A, Antinori A, Aloisi MS, et al. Depressive symptoms, neurocognitive impairment, and adherence to highly active antiretroviral therapy among HIV-infected persons. Psychosomatics. 2004;45:394-402.

133. Starace F, Ammassari A, Trotta MP, et al. Depression Is a risk factor for suboptimal adherence to highly active antiretroviral therapy. J Acquir Immune Defic Syndr. 2002;31(suppl 3):s136-s139.

134. Waldrop-Valverde D, Valverde E. Homelessness and psychological distress as contributors to antiretroviral nonadherence in HIV-positive injecting drug users. AIDS Patient Care STDS. 2005;19:326-334.

135. Kacanek D, Jacobson DL, Spiegelman D, Wanke C, Isaac R, Wilson IB. Incident depression symptoms are associated with poorer HAART adherence: a longitudinal analysis from the Nutrition for Healthy Living study. J Acquir Immune Defic Syndr. 2010;53:266-272.

136. Repetto MJ, Petitto JM. Psychopharmacology in HIV-infected patients. Psychosom Med. 2008;70(5):585-592.

137. Gallego L, Barreiro P, Lopez-Ibor JJ. Psychopharmacological treatments in HIV patients under antiretroviral therapy. AIDS Rev. 2012;14:101-111.

138. Kang E, Delzell DA, Chhabra M, Oberdorfer P. Factors associated with high rates of antiretroviral medication adherence among youth living with perinatal HIV in Thailand. Int J STD AIDS. 2015;26(8):534-541.

139. Vitello B, Burnam M, Bing E, Beckman R, Shapiro M. Use of psychotropic medications among HIV-infected patients in United States. Am J Psychiatry. 2003;160:547-554.

140. Freudenreich O, Goforth H, Cozza K, et al. Psychiatric treatment of persons with HIV/AIDS: an HIV-psychiatry consensus survey of current practices. Psychosomatics. 2010;51:480-488.

141. Omonuwa T, Goforth H, Preud'homme X, et al. The pharmacological management of insomnia in patients with HIV. J Clin Sleep Med. 2009;5:251-262.

142. Batki S. Buspirone in drug users with AIDS or AIDS - related complex. J Clin Psychopharmacol. 1990;10:111-115.

143. Greenblatt D, von Moltke L, Harmatz J, et al. Differential impairment of triazolam and zolpidem clearance by ritonavir. J Acquir Immune Defic Syndr. 2000;24:129-136.

144. Anderson I. Selective serotonin reuptake inhibitors versus tricyclic antidepressants; a meta-analysis of efficacy and tolerability. $J$ Affect Disord. 2000;58:19-36.

145. Grassi B, Gambini O, Garghentini G, Lazzarin A, Scarone S. Efficacy of paroxetine for treatment of depression in the context of HIV infection. Pharmacotherapy. 1997;30:70-71.

146. Fernando S, Rabkin J, de Moore G, Rabkin R. Antidepressant treatment of depression in HIV seropositive women. J Clin Psychiatry. 1999;60:741-746.

147. Baker G, Fang H, Sinha S, Coults R. Metabolic drug interactions with selective serotonin reuptake inhibitor (SSRI) antidepressants. Neurosci Biobehav Rev. 1998;22:325-333. 
148. Caballero J, Nahata M. Use of selective serotonin-reuptake inhibitors in the treatment of depression in adults with HIV. Ann Pharmacother. 2005;39:141-145.

149. Currier M, Molina G, Kato M. Citalopram treatment of major depressive disorder in Hispanic HIV and AIDS patients: a prospective study. Psychosomatics. 2004;45:210-216.

150. DeSilva KE, Le Flore DB, Marston BJ, Rimland D. Serotonin syndrome in HIV-infected individuals receiving antiretroviral therapy and fluoxetine. AIDS. 2001;15:1281-1285.

151. Horberg MA, Silverberg MJ, Hurley LB, et al. Effects of depression and selective serotonin reuptake inhibitor use on adherence to highly active antiretroviral therapy and on clinical outcomes in HIV-infected patients. J Acquir Immune Defic Syndr. 2008;47(3):384-390.

152. Elliott AJ, Uldall KK, Bergam K, Russo J, Claypoole K, Roy-Byrne PP. Randomized, placebo- controlled trial of paroxetine versus imipramine in depressed HIV-positive outpatients. Am J Psychiatry. 1998;155: 367-372.

153. Schwartz JAJ, McDaniel JS. Double-blind comparison of fluoxetine and desipramine in the treatment of depressed women with advanced HIV disease: a pilot study. Depress Anxiety. 1999;9(2):70-74.

154. Younai FS, Marcus M, Freed JR, et al. Self-reported oral dryness and HIV disease in a national sample of patients receiving medical care. Oral Surg Oral Med Oral Pathol Oral Radiol Endod. 2001; 92:629-636.

155. Elliott AJ, Russo J, Bergam K, Claypoole K, Uldall KK, Roy-Byrne PP. Antidepressant efficacy in HIV seropositive outpatients with major depressive disorder: an open trial of nefazodone. J Clin Psychiatry. 1999;60(4):226-231.

156. Elliott AJ, Roy-Byrne PP. Mirtazapine for depression in patients with human immunodeficiency virus. J Clin Psychopharmacol. 2000;20(2):265-267.

157. Ereshefsky L, Dugan D. Review of the pharmacokinetics, pharmacogenetics, and drug interaction potential of antidepressants: focus on venlafaxine. Depress Anxiety. 2000;12:30-44.

158. Currier M, Molina G, Kato M. A prospective trial of sustained release bupropion for depression in HIV-seropositive and AIDS patients. Psychosomatics. 2003;44:120-125.

159. Hesse LM, von Moltke LL, Shader RI, Greenblatt DJ. Ritonavir, efavirenz, and nelfinavir inhibit CYP2B6 activity in vitro: potential drug interactions with bupropion. Drug Metab Dispos. 2001;29: 100-102.

160. Carvarhal A, de Abreu P, Spode A, Correa J, Kapczinski F. An open trial of reboxetine in HIV-seropositive outpatients with major depressive disorder. J Clin Psychiatry. 2003;64:421-424.

161. Fernandez F, Levy JK, Samley HR, et al. Effects of methylphenidate in HIV-related depression: a comparative trial with desipramine. Int J Psychiatry Med. 1995;25:53-67.

162. Wagner GJ, Rabkin R. Effects of dextroamphetamine on depression and fatigue in men with HIV: a double-blind, placebo-controlled trial. J Clin Psychiatry. 2000;61:436-440.

163. Rabkin JG, Ferrando SJ, Wagner GJ, Rabkin R. DHEA treatment for HIV patients: effects on mood, androgenic and anabolic parameters. Psychoneuroendocrinology. 2000;25:53-68.

164. Lee MR, Cohen L, Hadley SW, Goodwin FK. Cognitive-behavioral group therapy with medication for depressed gay men with AIDS or symptomatic HIV infection. Psychiatr Serv. 1999;50:948-952.

165. Crepaz N, Passin WF, Herbst JH, et al. Meta-analysis of cognitivebehavioral interventions on HIV-positive persons' mental health and immune functioning. Health Psychol. 2008;27(1):4-14.

166. Spies G, Asmal L, Seedat S. Cognitive-behavioural interventions for mood and anxiety disorders in HIV: a systematic review. J Affect Disord. 2013;150(2):171-180.
167. Markowitz JC, Klerman GL, Clougherty KF, et al. Individual psychotherapies for depressed HIV positive patients. Am J Psychiatry. 1995;152:1504-1509.

168. Markowitz JC, Kocsis JH, Fishman B, et al. Treatment of depressive symptoms in human immunodeficiency virus-positive patient. Arch Gen Psychiatry. 1998;55:452-457.

169. Rousaud A, Blanch J, Hautzinger M, et al. Improvement of psychosocial adjustment to HIV-1 infection through a cognitive-behavioral oriented group psychotherapy program: a pilot study. AIDS Patient Care STDS. 2007;21(3):212-222.

170. Mulder CL, Emmelkamp PM, Antoni MH, Mulder JW, Sandfort TG, de Vries MJ. Cognitive behavioral and experiential group psychotherapy for HIV-infected homosexual men: a comparative study. Psychosom Med. 1994;56:423-431.

171. Lutgendorf SK, Antoni MH, Ironson G, et al. Cognitive-behavioral stress management decreases dysphoric mood and herpes simplex virus-type 2 antibody titers in symptomatic HIV seropositive gay men. J Consult Clin Psychol. 1997;65:31-43.

172. Cruess S, Antoni MH, Hayes A, et al. Changes in mood and depressive symptoms and related change processes during cognitive - behavioral stress management in HIV infected men. Cognit Ther Res. 2002; 26:373-392.

173. Blanch J, Rousaud A, Hautzinger M, et al. Assessment of the efficacy of a cognitive-behavioral group psychotherapy programme for HIV infected patients referred to a consultation-liaison psychiatry department. Psychother Psychosom. 2002;71:77-84.

174. Antoni MH, Cruess S, Cruess DG, et al. Cognitive-behavioral stress management reduces distress and 24-hour urinary free cortisol output among symptomatic HIV-infected gay men. Ann Behav Med. 2000;22:29-37.

175. Olatunji BO, Mimiaga MJ, O’Cleirigh C, Safren SA. A review of treatment studies of depression in HIV. Top HIV Med. 2006;14(3): $112-124$

176. Berger S, Schad T, von Wyl V, et al. Effects of cognitive behavioral stress management on HIV-1 RNA, CD4 cell counts and psychosocial parameters of HIV-infected persons. AIDS. 2008;22(6):767-775.

177. Brown JL, Vanable PA. Cognitive-behavioral stress management interventions for persons living with HIV: a review and critique of the literature. Ann Behav Med. 2008;35(1):26-40.

178. Scott-Sheldon LA, Kalichman SC, Carey MP, Fielder RL. Stress management interventions for HIV+ adults: a meta-analysis of randomized controlled trials, 1989 to 2006. Health Psychol. 2008;27(2):129-139.

179. Hemmati Sabet A, Khalatbari J, Abbas Ghorbani M, Haghighi M, Ahmadpanah M. Group training of stress management vs. group cognitive-behavioral therapy in reducing depression, anxiety and perceived stress among HIV-positive men. Iran J Psychiatry Behav Sci. 2013;7(1):4-8.

180. Vance DE, Humphrey SC, Nicholson WC, Jablonski-Jaudon R. Can speed of processing training ameliorate depressive symptomatology in adults with HIV? Ann Depress Anxiety. 2014;1(3):4.

181. Ngô TL. Review of the effects of mindfulness meditation on mental and physical health and its mechanisms of action. Sante Ment Que. 2013;38(2):19-34.

182. Hand GA, Lyerly GW, Jaggers JR, Dudgeon WD. Impact of aerobic and resistance exercise on the health of HIV-infected persons. Am J Lifestyle Med. 2009;3(6):489-499. 
Neurobehavioral HIV Medicine

Dovepress

\section{Publish your work in this journal}

Neurobehavioral HIV Medicine is an international, peer-reviewed, open access journal focusing on advances in research in HIV/ AIDS, with specific reference to the neurological, psychiatric and behavioral consequences of the disease, concomitant infections and specific antiretroviral therapy. The manuscript

management system is completely online and includes a very quick and fair peer-review system, which is all easy to use. Visit http://www.dovepress.com/testimonials.php to read real quotes from published authors.

Submit your manuscript here: http://www.dovepress.com/journal-of-neurobehavioral-hiv-medicine-journal 